\title{
THE UTILIZATION OF GOVERNMENT FINANCIAL STATEMENTS BY EXECUTIVES: \\ THE CASE OF LOCAL GOVERNMENTS IN INDONESIA
}

\author{
Nurkholis $^{1 *}$, Arlisya Tika Affandi ${ }^{1}$ \\ ${ }^{1}$ Faculty of Economics and Business, Brawijaya University
}

\begin{abstract}
The objective of this study is to explore the utilization of LKPD produced through the implementation of accrual accounting. Using the cases of three local governments in Indonesia, it is revealed that the implementation of accrual accounting is still superficial. As predicted, financial statements that are frequently used by executive's and local goverment are Budget Realization Statements and balance sheet. Other reports have been produced only to comply with government regulations, but they are not actually used. The implication of this study is that there is a need to improve executive's understanding about accrual accounting, so that the objective of financial reporting as stipulated in Government Regulation No. 71 of 2010 can be achieved.
\end{abstract}

Keywords: LKPD, accrual accounting, government accounting standards, executive perspectives 


\section{INTRODUCTION}

Recent public sector reform by applying New Public Management (NPM) arises from criticism to public sector management. The expectation behind the implementation of NPM is a better governance system in which the decision-making is not only guided by goverment rule but also considering the situation and condition of all elements in the bureaucracy (good government) (Anshoriy, 2008). The implementation of NPM resulted in changes in public sector accounting system in both its accountability and accounting basis (Bastian, 2005). Through this changes, it is expected that the government can improve the quality of the reporting that is used in decision-making process (Nogueira, Jorge, Oliver 2013; Nogueira \& Jorge, 2015).

In Indonesia fact, the changes in government accounting system has been gradual. The government initially applied cash-based accounting, followed by cash-towardsaccrual-based accounting (CTA), and finally full accrual accounting of which the implemention has been based on Government Regulation no. 71 of 2010 on Government Accounting System. Such implementation increases the complexity of Local Government Financial Statements (LKPD). The new standard required local goverment to prepare seven reports, namely Budget Realization Statements, Operational Report, Statement of Changes in Budget Surplus, Balance Sheet, Cash Flows Statement, Statement of Changes in Equity, and Notes to the Financial Statements.

One of the main users of LKPD is the executive of local government. The functions of LKPD for the executives are 1) as a form of accountability for resources they have managed and used (Regar, 2009), and 2) to improve the quality of decisions they are going to take (Mardiasmo, 2009). According to Jiwani (2010), it is possible that executives will face complexities, risks, and uncertainties in their decision-making. Accrual-based accounting emerged to minimize those possibilities through the depth of information for decision making. Accrual basis is believed to be able to provide better and comprehensive information, so all forms of transactions, conditions, and financial position of entities can be well identified (Hassan, 2015).

However, reality show the opposite. Cash based reports are still the focus of the government instead of the accrual basis (Susanto \& Djuminah, 2015; Wahyuni, 2016;). In fact, referring to Government Regulation no. 71 of 2010 and generally accepted 
accounting principles, cost incurred shall be proportional to the benefits gained. In other words, the use of accrual based financial statements should be proportional to the costs incurred for preparing them.

This study aims to determine the views of the Regional Government of Malang Raya as an executive in the use of LKPD for their decision making. Thus, the literature review of this article emphasizes the use of LKPD by executives, and discussion on previous researches follows. The method of this study will be described in the next section, while the results of this study will be elaborated and concluded to generate suggestions for further researches.

\section{LITERATURE REVIEW}

\section{Accounting in the Context of Public Sector Reform Implementation}

Public sector reform was conducted because there are parties who are dissatisfied with the performance of public entities (Bhuiyan \& Amagoh, 2010). The reform was done by applying NPM, a concept that combines public sector management with private sector management to improve the quality of the former (Hood, 1991). Some of the criteria adopted from private sector are free-to-manage system for all employees, clear standards and performance measurements, better supervision on outputs, establishment of work units in the public sector, competition among public entities, the use of flexible leadership systems, emphasis on discipline, prioritization of efficiency and effectiveness of resource usage (Hood, 1991).

The impact of public sector reform is the demand toward accounting system to provide a more detailed description on the actual cost of government transactions. In addition, changes occur in accountability, so the accounting basis has to shift from cash basis to accrual basis in the hope of improvement of financial statement's quality for the decision making (Nogueira et al, 2013; Nogueia \& Jorge, 2015). In Indonesia, accrual basis is applied gradually from (1) cash basis, (2) to cash-to-accrual basis (CTA), and finally to (3) full accrual basis based on Government Regulation number 71 of 2010 on Government Accounting Standards. The application of accrual basis causes the report components in LKPD more complex by requiring the preparation of Budget Realization Statements, Operational Report, Statement of Changes in Budget Balance, Balance

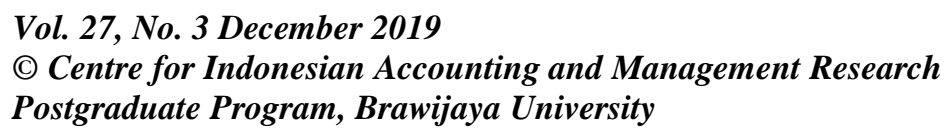


Sheet, Cash flow statement, Statement of Changes in Equity, and Notes to the Financial Statements.

Although the application of accrual basis has been compulsory, several researches mentioned that there are many parties who do not fully understand about the aforementioned basis (Abeysinghe \& Samanthi, 2016; Wahyuni, 2016). Subsequently, the implementation of accrual basis is overimposed and only used as a formality (Akbar et al, 2012: Harun \& Kamase, 2012). It is inferred from earlier researches that changes in the current accounting system are simply symbolic, not functional (Hassan, 2015).

\section{Decision-making in Public Sector}

Decision-making is the behavior of choosing from several available alternatives by collaborating some disciplines such as economics, politics, psychology, and public administration (Bastian, 2011). In public sector area, decision-making is also called as public policy formulation. According to Dunn (1999), the process of public policy formulation consists of: (1) preparation of policy agenda, (2) policy formulation, (3) policy adoption, (4) policy implementation, and (5) policy evaluation. In the decisionmaking process, decision makers must deal with various complexities, risks, and uncertainties, so certain approach needs to be taken to avoid undesired situation. The approach can be done by selecting available alternatives or by consulting the experts who have been in the similar situation before (Jiwani, 2010). Decision-making is usually influenced by internal and external factors. Internal factors include work experience, educational backgrounds, motives, perspectives, intuitions, assumptions, and interests, while external factors include economic and political condition and inter-governmental situation in the problematic or decision-making areas. 


\section{Public Sector Financial Statement}

Public sector financial statement is a tool of accountability from the government to the society regarding the management of public resources (Regar, 2009). The better the financial reporting, the higher the credibility and integrity of the state's finances becomes, which eventually improves public management (Kapardis et al, 2016). Mardiasmo (2009) argued that, in general, public sector financial statement is used to help economic, social, and political decision-making processes for interested parties. Users of public sector, or governmental, financial statement, are external and internal parties (Clark, 2001; Coy, 1997; Collins, 2001 in Kapardis et al., 2016). Internal parties are entities running the government or bureaucracy, while external parties are communities or parties domestic resources.

\section{Information Needs of Public Sector Financial Statement Users}

Based on Government Regulation No. 71 of 2010, information presented in public sector financial statement must meet some qualitative characteristics such as understandable, relevant, reliable, and comparable. Anthony in Wilson (1999) classified information needs of users into four major groups; they are (1) Financial viability information, which is information related to the availability of resources so that related entities are able to continue the plan they have made, (2) Fiscal compliance, which is information related to the compliance of entities to fiscal policy, (3) Management performance, which is information related to the effectiveness of budget realization, and

(4) Cost of services provided, which is information related to service cost.

\section{Public Sector Financial Statement Utilization by Executives}

Regulation No. 17 of 2003 Article 30 on State Finance explains that the executive acts as the party who plan, prepare, implement, and is responsible for the state's finances. Article 297 of Regulation of Minister of Internal Affairs No. 13 of 2006 on Guidelines for Regional Financial Management states that financial accountability is realized in financial statements that must be reported to the Indonesian Supreme Audit Institution no later than three months after the fiscal year ends. The financial statements are not only used as a form of liability but also as a consideration basis in decision making. There are

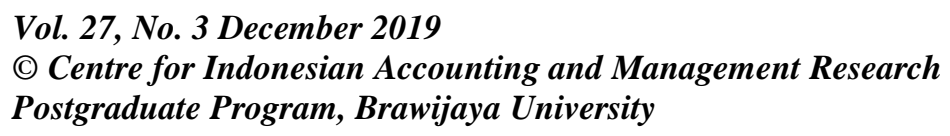


seven financial reports used by executives; they are Budget Realization Statements, Operational Report, Statement of Changes in Budget Balance, Balance Sheet, Cash flow statement, Statement of Changes in Equity, and Notes to the Financial Statements. The research of BPKP (2016) concluded that the seven reports have an important role in the decision making by executives.

\section{The Position of Executive in Governmental System}

The application of trias politica in Indonesian state administration system divides power into three parts; they are executive, legislature, and judiciary, where executive applies regulations, legislature establishes regulations, and judiciary adjudicates violation of laws and other applicable regulations. The synergy of the three is expected to create reciprocal supervision and balancing, so that the implementation of the function runs optimally (Budiardjo, 2008). Regulation No. 23 of 2014 on Regional Government stipulates that local governments only have executive and legislative power. The power of executive is held by the Regional Head assisted by the Regional Instrument such as the Secretary of Region, the Secretary of Regional House of Representatives (DPRD), Inspectorates, Services, Agencies, and Districts, while the power of legislature is in Regional House of Representatives.

\section{Previous Researches on the Use of Public Sector Financial Statement}

This research refers to the research of Brook (2010); Nogueira et al (2013); and Susanto \& Djuminah (2015). The conclusion from previous researches is that financial reports prepared by local governments have different degrees of utilization.

Local governments in Spain completes their financial statements with ratio to assist decision-making process. Local governments in the United States and Australia prepare financial statements only to meet the regulations and not for daily activities including decision-making processes. Differences in the use of financial statements in some countries are due to, among others, limitations of decision makers in understanding accounting, lack of accounting training in government agencies, lack of IT utilization and few number of resources capable of utilizing them, differences in needs according to the field of utilization, and the view that financial statements are not parts of the decision- 
making by entities.

\section{RESULT AND DISCUSSION}

Regulation No. 23 of 2014 on Regional Government explains that the Central Government authorizes Local Governments to manage their finances, so the power of regional financial management lies on the hand of Regional Heads. However, in carrying out their duties, they delegate a part or all of their power to regional instruments. The impact of the power transfer is the shift of decision-making authority from Regional Heads to the appointed regional instruments. Based on the explanation of echelon officials in Agency for Regional Finance and Assets Management (BPKAD) of Malang City and Malang Regency, the decision makers in the Local Government of Malang Raya are listed in Table 4.1

Table 4.1

Decision Makers in the Local Government of Malang Raya

\begin{tabular}{|c|c|c|}
\hline it of Malang & icy & $\begin{array}{l}\text { Government of Batu } \\
\text { City }\end{array}$ \\
\hline $\begin{array}{l}\text { - Regional Head (Mayor } \\
\text { and Deputy Mayor) } \\
\text { - Secretary of the City } \\
\text { - Assistant to Secretary } \\
\text { of the City } \\
\text { - Head of Agency for } \\
\text { Regional Finance and } \\
\text { Assets Management } \\
\text { (BPKAD) } \\
\text { - Head of Agency for } \\
\text { Regional Development } \\
\text { (Bappeda) } \\
\text { - Inspectors }\end{array}$ & $\begin{array}{l}\text { - Regional Head (Regent } \\
\text { dan Deputy Regent) } \\
\text { - Secretary of the Regency } \\
\text { - Assistant to Secretary of } \\
\text { the Regency } \\
\text { - Head of Agency for } \\
\text { Regional Finance and } \\
\text { Assets Management } \\
\text { (BPKAD) } \\
\text { - Head of Agency for } \\
\text { Regional Development } \\
\text { (Bappeda) } \\
\text { - Inspectors }\end{array}$ & 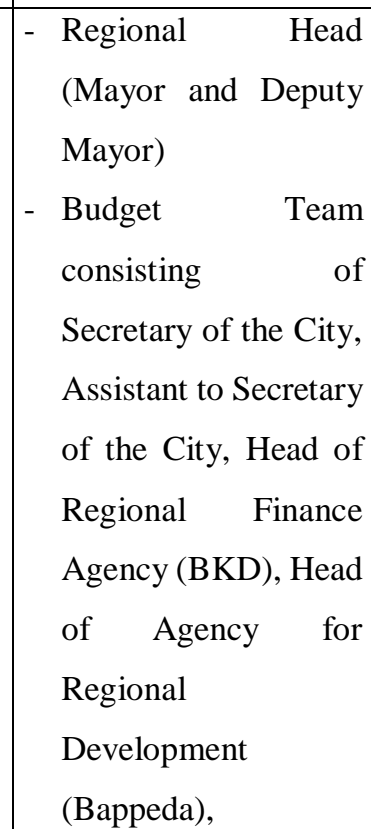 \\
\hline
\end{tabular}

Vol. 27, No. 3 December 2019

(C) Centre for Indonesian Accounting and Management Research Postgraduate Program, Brawijaya University 


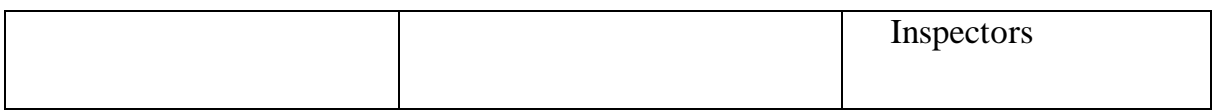

Source: Processed data, 2017.

Decision makers in the Regional Government of Malang Raya are Regional Heads and regional instruments such as the Secretary of the City or Regency, Heads of Boards, or Heads of Agencies. There are also departments responsible for the fulfillment of data requirements for decision-making purposes; they are Heads of Divisions, Heads of SubDivisions, and staff.

According to the explanation of the Head of Financial Agency of Batu City, the process of decision making in the Regional Government of Malang Raya includes identification of problems, formulation of alternative solutions, and decision making by selecting most effective and efficient alternatives. Based on Government Regulation No. 71 of 2010, the seven reporting elements of LKPD are instruments that must be used in the formulation of alternative solutions. Therefore, layered studies from staff level to leader level are conducted, so Regional Head is able to make the best decision. According to the Deputy Mayor of Malang and the Head of Government Planning Department of Bappeda in Malang Regency, the consideration of decision making process includes: (1) time of decision making, (2) effectiveness of expenses, (3) development of community culture, and (4) planning-document based decision. In addition to the four factors, an executive must pay attention to the output, outcomes, benefits, and impact of the resulting decisions.

The Utilization of Local Government Financial Statements by the Executive of Regional Government of Malang Raya

Government Regulation No. 71 of 2010 explains that, in accordance with generally accepted accounting principles, costs shall be proportional to the benefits. In addition, the explanation in previous sub-chapters mentions that the seven elements of LKPD must be used in the formulation of alternative solutions in decision making. However, the fact in the Regional Government of Malang Raya shows that the seven elements in LKPD are only used as a formality, which is a form of responsibility and regulatory fulfillment. 
"... the financial statement does report the accountability of internal performance, which is then examined by Indonesian Supreme Audit Institution; it is only a form of performance report to the public ..." (Secretary of Bappeda of Malang Regency)

Similar explanations were given by other informants. Thus, the executive in the Regional Government of Malang Raya is still not able to comprehensively interpret LKPD, and it affects the inadequate utilization of LKPD, both at staff level and leadership level. Akbar et al. (2012) argued that the current phenomenon is that the use of information in government financial statements is merely a form of formality, not an effort to improve the quality of the government.

Although the current utilization of LKPD is still not at the adequate level, the following is the utilization of LKPD by the executive in the Local Government of Malang Raya starting from the financial statements with the highest utilization frequency.

\section{Budget Realization Statements}

Budget Realization Statements is the most frequently used report by executives. The conclusion was obtained from interviews with Officials of BPKAD of Malang City, Officials of BPKAD of Malang Regency, and the Head of BKD of Batu City.

"... for the interest of the policy maker, whether it is regional head or the secretary of the city, Budget Realization Statements is the most frequently used, followed by balance sheet and Notes to the Financial Statements, because it is from Budget Realization Statements can we identify the remaining money at the end of a certain year. If we want to know the performance target of Regional Work Unit (SKPD), we also refer to Budget Realization Statements ... "

Based on the information, it is identified that, among the components of LKPD, Budget Realization Statements best suits executive's needs because it enables the executives to understand the performance of SKPD. In addition, executive uses Budget Realization Statements because (1) it evaluates the performance of SKPD, (2) it measures government service to the community, and (3) it evaluates the budgeting process. Executives tend to focus on the characteristics of agencies or SKPD when they read Budget Realization Statements. According to the Deputy Mayor of Malang, this is 
because the government is able to evaluate the performance of agencies or SKPD better through identification of agency's or SKPD's characteristics.

\section{Balance Sheet}

Balance Sheet is the second most frequently used report after Budget Realization Statements.

"... the first is the Budget Realization Statements, the second is the Balance Sheet ... It is through the Balance Sheet we know the structure of the local government's budget ... It is used as a reference in preparing the next budget, taking into account the expenses composition and structure which is close to ideal, adapted with local conditions. It aims to maximize budget absorption for development process and maximize the contribution of local revenue ... ". (Head of BKD of Batu City)

It can be concluded that balance sheet becomes a concern because it is considered as a reference that can be used in budgeting for the coming period and it can describe the spending structure of local government. In the study of Brusca (1997) in Spain, balance sheet is also a part of financial statements that is able to attract the attention of users after the Budget Realization Statements. However, some informants stated that the one who understand more about Balance Sheet is staff, not leader or head of departments. This is explained by Assistant 1 of Secretary of Batu city as follows:

"I do not really understand about it; the staff knows better than me. People in higher levels unexpectedly do not know much [laughing]. That is why if you want to hold an interview about this, staff is who you are looking for because they know more about the details of the post ..."

Thus, the understanding of executives about Balance Sheet is still poor. They tend to make judgments based on the explanations made by regional instrument under their supervision. In addition, there are also executives who have misperceptions about Balance Sheet. This is proved by excerpts of interviews between the researcher and the Head of Government Planning of Bappeda of Malang Regency as follows: 
“... so, I do not really remember the financial or accounting term, but it is clear here that the one being used is expenditure Balance Sheet and income Balance Sheet ..."

It appears that the informant cannot distinguish between Balance Sheet which is meant by the researcher (according to Government Regulation No. 71/2010) and Balance Sheet applicable during the New Order era. Although the executive's understandings are different, the interview results show that Balance Sheet is used (1) to control local assets, (2) to measure the overall regional wealth, and (3) to attract third parties (investors) to invest. The large amount of assets in balance sheet tends to be the focus of executives as it requires an effective management.

\section{Notes to the Financial Statements}

Notes to the Financial Statements is used by local governments to complete the financial information in all components of LKPD because executives must provide the information to BPK when the LKPD prepared by the local government is assessed (Assistant 1 of Secretary of Batu City). The fact is in accordance with the research of BPKP (2016), which explains that executives use Notes to the Financial Statements to know the policy underlying the value presented in LKPD. Furthermore, Notes to the Financial Statements is more likely to be used by parties who serve as inspectors and auditors (BPK).

\section{Cash Flow Statements}

The assumption from the executive that cash is the most vulnerable to be embezzled affects the emphasis of Cash Flow Statements utilization as a form of accountability of cash management. The Head of Income Accounting Sub Division of BPKAD of Malang Regency explains as follows

"... to know the amount of revenue and expenditure from cash. That is where leaders usually want to know the total value of cash received in a fiscal year, where the cash come from, the total value of cash spent, what for, and the total of the remaining cash ..." 
The excerpt explains that leaders, as the executive of the region, demand to know in detail about the management of the cash. In addition, executives also use Cash Flow Statements for several purposes such as controlling the performance of SKPD and monitoring the realization of budget. Governments tend to focus on the completeness of transactions recorded in Cash Flow Statements due to possible implications of the nominal presented in the Cash Flow Statements, for instance difference between recorded transaction and the available physical evidence. Moreover, according to some informants, cash managed by regional government has always been the highlight during BPK's audit.

\section{Statement of Changes in Budget Balance}

Statements of Changes in Budget Balance is not something new in LKPD. Before Government Regulation No. 24 of 2005 on Government Accounting Standards was revised into Government Regulation No. 71 of 2010, Statements of Changes in Budget Balance is not reported separately. Executives are able to see it through Budget Realization Statements, which is in the post of Budget Surplus/Deficit. However, since Statements of Changes in Budget Balance is reported separately, not all executives really understand the report. Here are explanations from some informants.

“... I wonder whether Statements of Changes in Budget Balance is in current year or in the end of year...?" (Secretary of BPKAD of Malang City)

“... Oh, it is returned to what we call as ben17. Ben17 means to the Region's Treasury. It is calculated based on Statements of Changes in Budget Balance, not spent by the services" (Assistant 1 of the Secretary of Batu City)

Based on the interview excerpt above, it appears that they do not understand much about the forms and substances of Statements of Changes in Budget Balance. When the respondents were asked about Agency for Regional Finance and Assets Management, most of them did not seem very sure about their responses. In fact, they tend to assume that Statements of Changes in Budget Balance only contains Budget Surplus/Deficit, 
without other posts like corrections on previous year's accounting errors or the use of Agency for Regional Finance and Assets Management.

Some of the executives who understand Statements of Changes in Budget Balance in the Local Government of Malang Raya tend to use Statements of Changes in Budget Balance to manage budget allocation as well as a tool for region's planning process. While reading Statements of Changes in Budget Balance, they tend to focus on year end Statements of Changes in Budget Balance post with an assumption that the post significantly influences the planning of the coming period.

\section{Operational Report and Statement of Changes in Equity}

Operational Report and Statements of Change in Equity are discussed simultaneously because most informants in this study discussed both reports simultaneously. Operational Report and Statements of Change in Equity are "new" reports resulting from the application of accrual basis in local government, so these two reports have only been prepared and used since 2015. The impact of the new implementation of Operational Report and Statements of Change in Equity is the lack of executive's understanding on the form and benefits of the report, so both are not fully utilized and only used to meet the applicable regulations. The following is an interview excerpt with the Secretary of BPKAD of Malang City.

“... What is the substance of operational repot? My background is not accounting, so I do not really understand. Since we have used accrual basis, it means that all of the reports must be used, must be complete in its presentation, and are used for auditing. Thus, the seven reports must be complete, in the sense that, if they are complete, they will be used. But if you ask me about their forms, recordings, calculations, or usage, I do not really understand ..."

Based on the excerpt above, Operational Report and Statements of Change in Equity are presented only to meet applicable regulations. The impact is limited understanding of executives about Operational Report and Statements of Change in Equity and the tendency of wasting local government's money due to insufficient usage of the reports. 
Based on the information from the informants, it appears that LKPD tends to be prepared to meet regulatory requirements and is not used optimally in government activities, especially in decision making. Executives tend to focus on Budget Realization Statements and Balance Sheet, which are considered capable of meeting their needs, while other reports tend to be ignored because of their limited understanding on those reports.

\section{Obstacles Faced by Executives of Regional Government of Malang Raya in Using}

\section{Local Government Financial Statements for Decision-Making Process}

Based on the previous discussion showing the nonoptimal use of LKPD by executives, the researchers held in-depth interviews to find out the cause. The results show that executives have different constraints in using financial statements. The constraints are as follows.

\section{Educational Background}

The limited understanding about LKPD is caused by irrelevance between the educational background of the regional instrument with accounting or finance major. The irrelevance in educational background can be seen in Table 4.2 below.

\section{Table 4.2}

\section{Educational Background of Informants}

\begin{tabular}{|c|c|}
\hline Informant & Education \\
\hline $\begin{array}{l}\text { 1.Deputy Mayor of Malang } \\
\text { 2.Secretary of BPKAD of Malang City } \\
\text { 3.Head of Accounting and Asset Administration } \\
\text { Department of BPKAD of Malang City }\end{array}$ & $\begin{array}{l}\text { 1. Undergraduate degree in theology } \\
\text { 2. Undergraduate degrees in economics, social } \\
\text { science, and public administration } \\
\text { 3. Undergraduate degree in Development } \\
\text { Economy }\end{array}$ \\
\hline $\begin{array}{l}\text { 1.Head of Income Accounting Sub-department of } \\
\text { BPKAD of Malang Regency } \\
\text { 2.Secretary of Bappeda of Malang Regency }\end{array}$ & 1. Undergraduate degree in finance \\
\hline
\end{tabular}




\begin{tabular}{|l|l|}
\hline $\begin{array}{l}\text { 3.Head of Government Planning of Bappeda of } \\
\text { Malang Regency }\end{array}$ & $\begin{array}{l}\text { 2. Undergraduate degree in corporate } \\
\text { management } \\
\text { 3. STPDN (School of Domestic Governance }\end{array}$ \\
\hline $\begin{array}{l}\text { 1.Head of Accounting Department of BKD of Batu } \\
\text { City }\end{array}$ & $\begin{array}{l}\text { 1. Undergraduate degree in accounting, graduate } \\
\text { degree in management }\end{array}$ \\
$\begin{array}{l}\text { 2.Assistant 1 to Secretary of Batu City } \\
\text { 3.Head of BKD of Batu City }\end{array}$ & $\begin{array}{l}\text { Undergraduate and graduate degrees in } \\
\text { management }\end{array}$ \\
\end{tabular}

Source: Processed data, 2017

The table reveals that the educational backgrounds of the informants are diverse and only a few of them have the educational background in accounting. No wonder if their understanding about accounting is poor. In addition, they explained that their educational backgrounds that are not related to accounting inhibited them from using financial statements.

\section{Misperception about Local Goverments Financial Statements Components}

Another factor that prevents executive from optimizing the use of LKPD is the misperception about, or incorrect way of seeing, the function of each financial report. The following is the interview excerpt between the researcher and the Head of Accounting Department of BKD of Batu City as informant number 7.

“... The relation is that, later on, Operational Report is for operation, yet Statement of Change in Equity is equity that only contains revisions. The two reports only contain last year's operations, so they are useless. The most important is that the ones that will certainly be used are reports prepared in the current year ..."

Based on the excerpt, the informant argued that Operational Report only reports operations, while Statement of Change in Equity only contains revisions. In fact, 
Operational Report and Statement of Change in Equity contain much information such as operational report income, operational report expenses, equity at the beginning of year, etc. Due to the misperception, the informant was unable to maximize the function of each post contained in Operational Report and Statement of Change in Equity.

\section{Perception that There are other Departments that Should Understand More about the Detail of Financial Reports}

As a controller of decision making process, an executive should understand about supporting data for decision making such as financial statements, infographics, and other supporting data. In the Regional Government of Malang Raya, it appears that upper level executives tend to rely on the analysis of staff or certain services or work units without really understanding the meaning of the figures presented in the financial statements. The phenomenon was identified from the interview excerpt between an informant and the researcher below.

“... So, here it is, Miss. Hold on. This question is very technical. I usually receive the gist from my subordinates, so I usually receive reports from them. [mimicking subordinates] Sir, for this one is like this, this is what happens. For the other one, it is like this. From the information, I provide them with solutions. [mimicking himself] Oh, you should do this. That is what I do more or less ..." (Deputy Mayor of Malang)

“... Thus, the seven reports must be complete, in the sense that, if they are complete, they will be used. But if you ask me about their forms, recordings, calculations, usage, I do not really understand. In general, I know, but if you need a more detailed explanation, it's better for you to go to accounting department ..." (Secretary of BPKAD of Malang City)

Based on the two excerpts above, an in-depth understanding on financial statements is not an urgent matter as long as there are others people who help analyze the report. The impact is that it opens the opportunity for staff or other services/work units to commit fraud. 


\title{
Limited Knowledge on Accrual Basis
}

The implementation of accrual basis in the Regional Government of Malang Raya was started simultaneously in 2015. The implementation forces executives to understand the characteristics of accrual basis, in terms of account type, account characteristics, and recording method. The goal is to make executives able to use reports they are going to prepare. However, in reality, the limited understanding of executives on accrual basis by pretending that they are not accustomed to the new basis makes them tend to ignore reports generated from accrual basis.

Head of Accounting Department of BKD of Batu City as Informant number 7 also explained that accrual basis will always be difficult to optimize if budgeting and reporting are made using different bases. The informant assumes that gap will always arise as long as the budgeting still uses cash basis yet the reporting still uses accrual basis.

\section{Perception that Financial Statements are Only Used for Accountability Formality}

Government Regulation No. 71 of 2010 on Government Accounting Standards explains that, in accordance with accounting principles, costs incurred must be proportional to the benefits received, so the preparation of financial statements should provide more benefits for their users. However, the current reality is that there are still executives who think that financial statements are only an instrument used for BPK audits and used as a form of accountability to the public. The phenomenon is evident from the explanation of some informants as follows.

“... the financial statements report the accountability of internal performance, which will usually be scrutinized by BPK, that is all, to report accountability to the public ..." (Secretary of Bappeda of Malang Regency)

"... of course, they are used, which eventually ends in accountability, ends in audit, inspector's audit, BPK's audit ..." (Assistant 1 of Secretary of Batu City)

\author{
Vol. 27, No. 3 December 2019 \\ (C) Centre for Indonesian Accounting and Management Research \\ Postgraduate Program, Brawijaya University
}


Excerpts from the opinions of two informants above show that executives are not really able to understand and optimize the utilization of LKPD. Their focus is only on the fact that LKPD must be prepared as a form of financial accountability, but the real benefits of LKPD in decision-making are ignored.

\section{Financial Statements Do Not Completely Describe Local Governments' Performance}

Another cause is that some components of LKPD are not able to comprehensively describe the performance of local governments. The Head of BKD as informant number 9 conveyed the following.

“...The financial statements do not fully reflect the performance of local government organizations, as the implementation of activities is frequently not accompanied with budget disbursement process, so there is a lag of time..."

Based on the information, it appears that the slow budget disbursement process in the implementation of activities causes some things not presented in the financial statements. It compromises the quality of financial statements, and users are not able to assess the real performance of local government organizations as executives. In fact, Government Regulation No. 71 of 2010 explains that one of the functions of financial statements is to assess performance. Thus, it can be said that the inability of financial statements to describe the real performance of local government organizations is an abuse toward applicable regulation or legal requirement.

\section{CONCLUSION AND SUGGESTION FOR FUTURE RESEARCHES}

Based on the discussion, this study concludes that:

1. The utilization of LKPD in decision-making by the executive tends to be conducted only to meet regulation requirements or coercive factors from applicable legislation.

2. Inhibitors for executives from using LKPD are: 
a. The educational backgrounds of the informants are diverse, and only a few of them have the educational background of accounting.

b. Misperception and misunderstanding of government as the executive about Government Regulation No. 71 of 2010 on forms and functions of LKPD.

c. Perception that there are other departments that should understand more about the detail of financial reports.

d. Limited knowledge of the government as the executive on definitions and usage of accrual basis.

e. Perception shared among the government as the executive that LKPD is only used as a formality of regional financial management accountability.

f. The current quality of the government's financial statement that is not able to describe the real performance of local government organizations

The discussion above is expected to make the Regional Government of Malang Raya, 1) able to improve the quality of decision making, and 2) able to increase the awareness of executives in using LKPD through discussion about the function of each component of LKPD. Thus, the seven elements of LKPD can be used optimally in accordance with the mandate of Government Regulation No. 71 of 2010.

This study is limited in terms of that 1) this study cannot interview the main decision makers, i.e. the mayors, since they have tight schedules; 2) the exploration on financialstatement-based decision-making is not well elaborated because the information provided by the executive is too general and fails to explain the real use of financial statements in decision making in detail, and 3) executives do not give explicit information because they think that the detailed utilization of financial statements is classified, so the researchers are only able to interpret the data in general ways.

Due to the limitations, similar researches capable of exploring the perspective of Regional Heads are necessary. The researchers believe that there are more details of decision making process known by mayors as the main decision makers. In addition, further researches should focus on the use of each LKPD component and expand the scope of its data, so they contribute more to the government, at both local and central government levels. Thus, the results of the studies can provide more significant descriptions and benefits for the local and central governments. 


\section{BIBLIOGRAPHY}

Abeysinghe, C. \& Samanthi, D. (2016). Accrual Basis and Political Interest in Public Sector Accounting: The Case of a Municipal Council in Sri Lanka. International Journal of Academic Research in Accounting, Finance, and Management Sciences, $6(3)$.

Abidin, S. Z. (2004). Kebijakan Publik. Jakarta: Yayasan Pancur Siwah.

Akbar, R., Pilcher, R., \& Perrin, B. (2012). Performance Measurement in Indonesia: The Case of Local Government. Pacific Accounting Review, 24(3), 262-291.

Amriani, T. N. (2014). Menyongsong Penerapan Akuntansi Pemerintahan Berbasis Akrual. Badan Pendidikan dan Pelatihan Keuangan Kementerian Keuangan: Makassar. Diakses melalui http://www.bppk.kemenkeu.go.id/beritamakassar/19410-menyongsong-penerapan-akuntansi-pemerintahan-berbasisakrual

Anshoriy, H.M. (2008). Dekonstruksi Kekuasaan: Konsolidasi Semangat Kebangsaan. Yogyakararta: LKIS.

Bastian, I. (2011). Sistem Akuntansi Sektor Publik. Jakarta: Salemba Empat.

Bhuiyan, S., \& Amagoh, F. (2011). Public Sector Reform in Kazakhstan: Issues and Perspectives. International Journal of Public Sector Management, 24(3).

Brook, D. A. (2013). Audited Financial Statements in The US Federal Government: The Question of Policy and Management Utility. Journal of Public Budgeting, Accounting, and Financial Management, 25(1), 52-83.

Brusca, I. (1997). The Usefulness of Financial Reporting in Spanish Local Government. Financial Accountability and Management, 13(1), 17-34.

Budiardjo, Miriam. (2008). Dasar-dasar Ilmu Politik. Jakarta: PT. Gramedia Pustaka Utama.

Creswell, J. W. (2009). Research Design: Pendekatan Kualitatif, Kuantitatif, dan Mixed. Yogyakarta: Pustaka Pelajar.

Daniels, J., \& Daniels, C. (1991). Municipal Financial Reports, What Users Want. Journal of Accounting and Public Policy Vol.10 No.1, 15-38.

Dunn, William N. (1999). Analisis Kebijakan Publik. Yogyakarta: Gajah Mada University Press. 
Goddard, A., \& Mkasiwa, T. (2016). New Public Management and Budgeting Practices in Tanzanian Central Government: Struggling for Conformance. Journal of Accounting in Emerging Economies, 6(4), 58-68.

Harun H., Peursem, K.V., \& Eggleton, I.R.C. (2015). Indonesian Public Sector Acounting Reform: Dialogic Aspiration A Step Too Far?. Accounting, Auditing, \& Accountability Journal, 28(5), 706-738.

Harun, H., \& Kamase, H.P. (2012). Accounting Change and Institutional Capacity: The Case of Provincial Government in Indonesia. Australian Accounting Business \& Finance Journal, 6(2), 35-50.

Hassan, M. M. (2015). Transformation to More-Accrual-Based Accounting Practices in Indonesian Government. Journal of International Business Research, 14(1), 139165.

Herdiansyah, H. (2010). Metodologi Penelitian Kualitatif untuk Ilmu-ilmu Sosial. Jakarta: Salemba Humanika

Heyer, G.D. (2011). New Public Management: A Strategy for Democratic Police Reform in Transitioning and Developing Countries. Policing: An International Journal of Police Strategies \& Management, 34(3), 419-433.

Hood, C. (1991). A Public Management for All Seasons?. Public Administration, 69. 319.

Hwang, C. J. (2006). Merging Libraries and Computing Centers in Taiwan: Factors Affecting Decision-making. Dissertation: Emporia State University.

James, O. \& Manning, N. (1996). Public Management Reform: a Global Perspective. Politics, 16(3), 143-149.

Jiwani, G. (2010). Uncovering the Unknown of Government Policy Decision Making Process at Senior Levels: Multiple Case Study. Dissertation: University of Washington.

Jones, R., Scott, R., \& Ingram, L. K. (1985). The Needs of Users of Governmental Financial Reports. Government Accounting Standards Board. Stamford

Kapardis M.K. \& Clark, C. (2010). Public Sector Financial Reporting: A User Needs Study in Cyprus. Nicosia: As Printxpress Ltd. 
Kapardis M.K., Clark, C., \& Zopiatis, A. (2016). Satisfaction Gap in Public Sector Financial Reporting. International Journal of Accounting in Emerging Economies, 6(3), 232-253.

Mack, J. \& Ryan, C. (2006). Reflection on The Theoretical Underpinnings of The General-Purpose Financial Reports of Australian Government Departments. Accounting, Auditing, \& Accountability Journal, 19(4), 592-612.

Mardiasmo. (2009). Akuntansi Sektor Publik. Yogyakarta: Andi.

Miles, B. M. \& Hubermen, A. M. (1992). Analisis Data Kualitatif: Buku Sumber tentang Metode-metode Baru. Jakarta: UI Press.

Moleong, L. J. (2010). Metodologi Penelitian Kualitatif. Bandung: Remaja Rosdakarya. Nogueira, S.P., Jorge, S.M., \& Oliver, M.C. (2013). The Usefulness of Financial Reporting for Internal Decision-Making in Portuguese Municipalities. Management Research: The Journal of the Iberoamerican Academy of Management, 11(2), 178212.

Nogueira, S.P. \& Jorge,S.M. (2015). Explanatory Factors for The Use of Financial Report in Decision-Making: Evidence from Local Government in Portugal. Revista de Contabilidad - Spanish Accounting Review, 19(2), 216-226.

Peraturan Menteri Dalam Negeri No. 64 Tahun 2013 tentang Penerapan Standar Akuntansi Pemerintahan Berbasis Akrual pada Pemerintahan Daerah.

Peraturan Pemerintah No. 24 Tahun 2005 tentang Standar Akuntansi Pemerintahan.

Peraturan Pemerintah No. 71 Tahun 2010 tentang Standar Akuntansi Pemerintahan.

Pusat Diklat Pengawasan BPKP: Efektivitas Laporan Keuangan Pemerintah Daerah dalam Mendukung Pengambilan Keputusan Manajemen Daerah 2016.

Ranney, A. (1971). The Governing of Men. New York: Holt, Rine Hart, and Winston Inc. Regar, M. H. (2009). Amburadul Jilid 2: Laporan Keuangan Pemerintah Pusat. Medan: USU Press.

Ribeiro, L. M., Pereira, J.R., \& Benedicto, G.C. (2013). The Role of Accounting in Public Governance Process. African Journal of Business Management, 7(29), 2905-2915. Rogers, E. M. (2003). Diffusion of Innovations, $5^{\text {th }}$ Ed. New York: Free Press Sadjiarto, A. (2000). Akuntabilitas dan Pengukuran Kinerja Pemerintahan. Jurnal Akuntansi dan Keuangan, 2(2), 138-150. 
Sekaran, U. (2006). Metodologi Penelitian untuk Bisnis, Edisi 4, Buku 1. Jakarta: Salemba Empat.

Sekaran, U. (2006). Metodologi Penelitian untuk Bisnis, Edisi 4, Buku 2. Jakarta: Salemba Empat.

Stein, N. (2000). The ASB's Revised Statement of Principles for Financial Reporting ACCA Student's News Letter. UK: Certified Public Accountants Educational Trust.

Sumantri, D. A. (1984). Arus Kebijaksanaan dan Pengambilan Keputusan di Wilayah/ Daerah. Jurnal Hukum \& Pembangunan, 14(2), 156-161..

Susanto, D, \& Djuminah. (2015). The Usefulness of LKPD for Regional Development Planning Process (An Empirical Study Against the Head of The District Development Planning Agencies in Java and Madura). Procedia-Social and Behavioral Sciences, 211, 75-80.

Undang-Undang No. 17 Tahun 2003 tentang Keuangan Negara.

Undang-Undang No. 23 Tahun 2014 tentang Pemerintahan Daerah.

Wahyuni, N.E. (2016). Analisis Implementasi Standar Akuntansi Pemerintahan Berbasis Akrual dalam Perspektif Teori Institusional: Studi Kasus pada Pemerintah Kota Malang. Skripsi: Universitas Brawijaya.

Wilson, J. (Ed.). (1999). Financial Management for the Public Services. Buckingham, Philadelphia: Open University Press.

Yin, R. K. (2015). Studi Kasus: Desain \& Metode. Jakarta: Rajawali Pers. 